\title{
Vancomycin trough level and loading dose
}

This article was published in the following Dove Press journal:

Infection and Drug Resistance

\section{Felipe Francisco Tuon' \\ Rudson Romero ${ }^{2}$ \\ Juliano Gasparetto ${ }^{2}$ \\ Juliette Cieslinski'}

'Laboratory of Microbiology and Emerging Infectious Diseases, Pontifícia Universidade Católica do Paraná, Curitiba, Paraná, Brazil; ${ }^{2}$ School of Medicine, Pontifícia Universidade Católica do Paraná, Curitiba, Paraná, Brazil
Correspondence: Felipe Francisco Tuon Laboratory of Microbiology and Emerging Infectious Diseases, Pontifícia Universidade Católica do Paraná, Rua Imaculada Conceição II55, 80.2I5-90I

Curitiba, PR, Brazil

Tel +55 4l 98852 I893

Email felipe.tuon@pucpr.br

\section{Dear editor}

We read with interest the paper by Barceló-Vidal et al ${ }^{1}$ about vancomycin nephrotoxicity due to high trough levels with histopathology. The authors described a case developing both lesions and described total vancomycin washout after a biopsy-proven vancomycin toxicity. Unfortunately, most patients receiving the loading dose of $>25 \mathrm{mg} / \mathrm{kg}$ do not achieve adequate trough level, which was recommended by some guidelines to be between 15 and $20 \mathrm{mg} / \mathrm{L} .{ }^{2}$ Considering this issue, we performed a brief study in two Brazilian hospitals with therapeutic drug monitoring (TDM) of vancomycin and loading dose of $30 \mathrm{mg} / \mathrm{kg}$. The inclusion criteria for the retrospective observational study were as follows: patients were aged $>18$ years, admitted to an intensive care unit (ICU), with infection, and received at least 72 hours of vancomycin, with the creatinine level of $<1.5 \mathrm{mg} / \mathrm{dL}$ in the first day of vancomycin.

All patients received $30 \mathrm{mg} / \mathrm{kg}$ of loading dose, and vancomycin trough level was obtained before the fifth dose. In obese patients, the dose was according to adjusted body weight. Vancomycin was prescribed with intermittent dose of $15 \mathrm{mg} / \mathrm{kg}$ every 12 hours. The following outcomes were analyzed: all-cause mortality, acute kidney injury (AKI), and trough level $<15 \mathrm{mg} / \mathrm{L}$. AKI was classified according to Acute Kidney Injury Network (AKIN) criteria. ${ }^{3}$ Risk factors were calculated according to the variable and its distribution and considered statistically significant when there was a difference of $<5 \%(P<0.05)$. For the multivariate analysis, all variables with statistical significance in the univariate analysis were included in a binary logistic regression.

Results from 164 patients are summarized in Table 1 . Trough level was $>15 \mathrm{mg} / \mathrm{L}$ in $76.8 \%(\mathrm{n}=126)$. Only $13.4 \%(\mathrm{n}=22)$ achieved the "ideal level" $(15-20 \mathrm{mg} / \mathrm{L})$; however, 18.9\% $(\mathrm{n}=31)$ achieved levels between 20 and $30 \mathrm{mg} / \mathrm{L}$ and $44.5 \%(\mathrm{n}=69)$ achieved levels higher than $30 \mathrm{mg} / \mathrm{L}$. No risk factor was associated with lower/ higher levels of vancomycin. Nevertheless, age, concomitant use of aminoglycoside, systemic arterial hypertension, and vancomycin trough level $>30 \mathrm{mg} / \mathrm{L}$ were associated with AKI. Vancomycin trough level of $>30 \mathrm{mg} / \mathrm{L}$ was an independent risk factor for AKI. The all-cause mortality was $44.5 \%$. The risk factor associated with death in the final model of multivariate analysis was AKI, and vancomycin trough level was $>30 \mathrm{mg} / \mathrm{L}$. 
Table I Clinical, laboratorial and outcome data of patients treated with vancomycin

\begin{tabular}{|c|c|c|c|c|c|c|c|}
\hline \multirow[t]{2}{*}{ Variables } & \multicolumn{2}{|l|}{ Total } & \multicolumn{2}{|l|}{ AKI } & \multicolumn{2}{|c|}{ Without AKI } & \multirow[b]{2}{*}{$P$-value } \\
\hline & $N=164$ & $\%$ & $\mathbf{N}=74$ & $\%$ & $\mathbf{N}=90$ & $\%$ & \\
\hline Female & 69 & 42.1 & 35 & 21.3 & 34 & 20.7 & 0.219 \\
\hline Death & 73 & 44.5 & 45 & 27.4 & 28 & 17.1 & 0.001 \\
\hline Aminoglycoside & 28 & 17.1 & 18 & II & 10 & 6.1 & 0.025 \\
\hline Polymyxin & 32 & 19.5 & 18 & II & 14 & 8.5 & 0.159 \\
\hline Previous admission in ICU & 4 & 2.4 & 2 & 1.2 & 2 & 1.2 & 0.843 \\
\hline HIV & 5 & 3 & 2 & 1.2 & 3 & 1.8 & 0.815 \\
\hline Diabetes & 22 & 13.4 & 12 & 7.3 & 10 & 6.1 & 0.34 \\
\hline Previous myocardial infarction & 14 & 8.5 & 8 & 4.9 & 6 & 3.7 & 0.345 \\
\hline Congestive heart failure & 10 & 6.1 & 6 & 3.7 & 4 & 2.4 & 0.329 \\
\hline Peripheral vascular disease & 15 & 9.1 & 8 & 4.9 & 7 & 4.3 & 0.503 \\
\hline Cerebrovascular disease & 21 & 12.8 & 11 & 6.7 & 10 & 6.1 & 0.474 \\
\hline Dementia & 6 & 3.7 & 5 & 3 & I & 0.6 & 0.055 \\
\hline Chronic pulmonary disease & $\mathrm{II}$ & 6.7 & 4 & 2.4 & 7 & 4.3 & 0.546 \\
\hline Systemic arterial hypertension & 77 & 47 & 42 & 25.6 & 35 & 21.3 & 0.023 \\
\hline Neoplasm & 18 & 11 & 7 & 4.3 & $\mathrm{II}$ & 6.7 & 0.573 \\
\hline Previous corticoid therapy & 4 & 2.4 & $\mathrm{I}$ & 0.6 & 3 & 1.8 & 0.413 \\
\hline Immunosuppression & 9 & 5.5 & 3 & 1.8 & 6 & 3.7 & 0.465 \\
\hline Trauma & 44 & 26.8 & 17 & 10.4 & 27 & 16.5 & 0.312 \\
\hline Emergency surgery & 16 & 9.8 & 8 & 4.9 & 8 & 4.9 & 0.68 \\
\hline Elective surgery & 60 & 36.6 & 29 & 17.7 & 31 & 18.9 & 0.53 \\
\hline Serum level of vancomycin $>30 \mathrm{mg} / \mathrm{L}$ & 91 & 55.5 & 30 & 18.3 & 61 & 37.2 & 0.001 \\
\hline Age (mean $\pm S D)$ (years) & 56.1 & 19.5 & 61.4 & 18.4 & 52.0 & 19.4 & 0.002 \\
\hline Hospitalization (mean $\pm \mathrm{SD}$ ) & 35.8 & 25.1 & 34.6 & 23.8 & 36.8 & 26.2 & 0.583 \\
\hline Charlson (mean \pm SD) & 1.2 & 1.6 & 1.2 & $\mathrm{I} .4$ & 1.2 & 1.8 & 0.967 \\
\hline $\mathrm{Cr}$ admission (mean $\pm \mathrm{SD})$ & I.I & 1.3 & I.I & 1.0 & 1.0 & 1.6 & 0.644 \\
\hline Cr, first day of vancomycin (mean $\pm \mathrm{SD})$ & 0.7 & 0.4 & 0.7 & 0.4 & 0.6 & 0.3 & 0.302 \\
\hline First vancomycin serum level (mean \pm SD) & 29.9 & 17.5 & 34.7 & 17.5 & 26.0 & 16.6 & 0.001 \\
\hline
\end{tabular}

Abbreviations: $\mathrm{AKI}$, acute kidney injury; $\mathrm{Cr}$, creatinine; ICU, intensive care unit.

After reading the paper by Barceló-Vidal et al, ${ }^{1}$ we also performed an analysis of patients with vancomycin trough level of $>60 \mathrm{mg} / \mathrm{L}$. From 164 patients, six had vancomycin trough level of $>60 \mathrm{mg} / \mathrm{L}$, and $50 \%(3 / 6)$ had severe AKI (AKIN 3): OR=5.38 (95\% CI: 1.02-27.87; $P<0.05)$.

Higher loading dose of vancomycin is necessary to achieve ideal therapeutic level of vancomycin. Unfortunately, this approach has the consequence of higher rates of AKI, which increases mortality. The only modifiable risk factor for AKI was vancomycin trough level of $>30 \mathrm{mg} / \mathrm{L}$. At this aspect, we should discuss alternatives to vancomycin in severe AKI patients or assume the consequences of ideal therapeutic levels with more AKI.

\section{Disclosure}

Felipe Francisco Tuon is a Conselho Nacional de Pesquisa (CNPQ) researcher. The other authors report no conflicts of interest in this communication.

\section{References}

1. Barceló-Vidal J, Rodríguez-García E, Grau S. Extremely high levels of vancomycin can cause severe renal toxicity. Infect Drug Resist. 2018;11:1027-1030.

2. Rybak MJ, Lomaestro BM, Rotschafer JC, et al. Therapeutic monitoring of vancomycin in adults summary of consensus recommendations from the American Society of Health-System Pharmacists, the Infectious Diseases Society of America, and the Society of Infectious Diseases Pharmacists. Pharmacotherapy. 2009;29(11):1275-1279.

3. Bagshaw SM, George C, Bellomo R; ANZICS Database Management Committe. A comparison of the RIFLE and AKIN criteria for acute kidney injury in critically ill patients. Nephrol Dial Transplant. 2008;23(5):1569-1574. 


\section{Authors' reply}

Jaime Barceló-Vidal,' Eva Rodríguez-García, ${ }^{2}$ Santiago $\mathrm{Grau}^{3}$

'Department of Pharmacy, Hospital del Mar, Parc de Salut Mar, Barcelona, Spain; ${ }^{2}$ Department of Nephrology, Hospital del Mar, Parc de Salut Mar, Barcelona, Spain; ${ }^{3}$ Department of Pharmacy, Hospital del Mar, Parc de Salut Mar, Universitat Autònoma de Barcelona, Barcelona, Spain

Correspondence: Santiago Grau

Department of Pharmacy, Hospital del Mar, Parc de Salut Mar,

Universitat Autònoma de Barcelona, Passeig Marítim, 25-29, 08003

Barcelona, Spain

Tel +3432483154

Fax +3432483256

Email sgrau@parcdesalutmar.cat

\section{Dear editor}

We read with interest the study by Tuon et al about the loading dose and therapeutic drug monitoring (TDM) of vancomycin in patients in intensive care units (ICUs). In the study, the authors highlight the significance to perform TDM in patients receiving vancomycin, since $<15 \%$ of their patients achieved ideal levels. On the other hand, $>60 \%$ of these patients had supratherapeutic levels. In addition, all-cause mortality had a high percentage. These results are alarming, and the authors conclude that some alternatives to vancomycin should be given to severe patients, but these patients can also benefit from this antibiotic as long as their use and monitoring are optimized.

Although the loading dose of $30 \mathrm{mg} / \mathrm{kg}$ was according to adjusted body weight in obese patients included in the reference study, the obese criteria in these patients are not defined. Moreover, it is known that not only obese patients but also those who are overweight (body mass index $25-30 \mathrm{~kg} / \mathrm{m}^{2}$ ) can be overdosed when the loading dose of vancomycin is calculated according to the total body weight. ${ }^{1}$ Furthermore, patients' demographics such as weight should also be described in the table, since it would be interesting to know the mean weight of this population.

In relation to the all-cause mortality rate and considering ICU patients, it is necessary to have a severity score such as APACHE II/III or SOFA and not just a Charlson score, which is actually a comorbidity index and its representation about critically ill patients is limited. ${ }^{2,3}$ Moreover, the authors describe severe acute kidney injury (AKI) in 50\% of patients with vancomycin trough level of $>30 \mu \mathrm{g} / \mathrm{mL}$, and AKI was associated with all-cause mortality rate. Considering critically ill patients, there are no data available on renal function evolution; probably, the best way to avoid this AKI is daily monitoring of renal function (serum creatinine, glomerular filtration rate, and need of hemodialysis) and adjusting vancomycin dosage depending on these variables.

In the study, following the latest recommendations from the Infectious Diseases Society of America (IDSA; 2009), a trough level of $15-20 \mu \mathrm{g} / \mathrm{mL}$ is considered to be the "ideal level". Nevertheless, recent studies have described that TDM of vancomycin using the pharmacokinetic/pharmacodynamic (PK/PD) parameter area under the curve/minimal inhibitory concentration (AUC/MIC) has the same clinical outcomes regarding effectiveness as the trough method, but presented less incidence of AKI. Based on these results, TDM of vancomycin should take the lead to obtain these $\mathrm{PK} / \mathrm{PD}$ parameters and try to achieve an AUC/MIC of $400-700 \mu \mathrm{g} / \mathrm{mL} \times \mathrm{h}$ since the trough method could lead to greater AUC values, which could be produced in a higher rate of AKI ${ }^{4,5}$

Finally, it would be interesting if more information could be obtained about these patients with trough values of $>60 \mu \mathrm{g} /$ $\mathrm{mL}$ if the kind of kidney injury is similar to our case, and also about the time it took for these patients to have undetectable vancomycin levels.

\section{Disclosure}

The authors report no conflicts of interest in this communication.

\section{References}

1. Leong JVB, Boro MS, Winter ME. Determining vancomycin clearance in an overweight and obese population. Am J Heal Pharm. 2011;68(7):599-603.

2. Saleh A, Ahmed M, Sultan I, Abdel-lateif A. Comparison of the mortality prediction of different ICU scoring systems (APACHE II and III, SAPS II, and SOFA) in a single-center ICU subpopulation with acute respiratory distress syndrome. Egypt J Chest Dis Tuberc. 2015;64(4):843-848.

3. Roffman CE, Buchanan J, Allison GT. Charlson Comorbidities Index. J Physiother. 2016;62(3):171.

4. Finch NA, Zasowski EJ, Murray KP, et al. A quasi-experiment to study the impact of vancomycin area under the concentration-time curve-guided dosing on vancomycin-associated nephrotoxicity. Antimicrob Agents Chemother. 2017;61(22):e01293-17.

5. Neely MN, Kato L, Youn G, et al. Prospective trial on the use of trough concentration versus area under the curve to determine therapeutic vancomycin dosing. Antimicrob Agents Chemother. 2018;62(2): e02042-17. 
Dove Medical Press encourages responsible, free and frank academic debate. The content of the Infection and Drug Resistance 'letters to the editor' section does not necessarily represent the views of Dove Medical Press, its officers, agents, employees, related entities or the Infection and Drug Resistance editors. While all reasonable steps have been taken to confirm the content of each letter, Dove Medical Press accepts no liability in respect of the content of any letter, nor is it responsible for the content and accuracy of any letter to the editor.

Infection and Drug Resistance is an international, peer-reviewed openaccess journal that focuses on the optimal treatment of infection (bacterial, fungal and viral) and the development and institution of preventive strategies to minimize the development and spread of resistance. The journal is specifically concerned with the epidemiology of antibiotic resistance and the mechanisms of resistance development and diffusion in both hospitals and the community. The manuscript management system is completely online and includes a very quick and fair peerreview system, which is all easy to use. Visit http://www.dovepress.com/ testimonials.php to read real quotes from published authors.

Submit your manuscript here: https://www.dovepress.com/infection-and-drug-resistance-journal 